\title{
The Role of Group Therapy in Developing Social Relationships for those Recovering from Addiction
}

"A study applied to social workers and recovering from addiction"

\section{Wesam Mohamed Ibrahim (PhD)}

with Groups Department Assistant Professor at working Faculty of Social work - Helwan University

\section{O melsaad Fathi Ibrahim (PhD)}

Assistant Professor at working with Groups Department

Faculty of Social work - Helwan University 



\section{Abstract:}

This study aims to determine the role of group therapy in developing social relationships for those recovering from addiction, The study has been applied to an intentional sample of 25 social workers and 65recovering from addiction in hospitals addiction. The study results indicated that the role of group therapy in developing social relationships for those recovering from addiction with their families and colleagues is of high significance at (0.01).However, there are no statistically significant differences between the opinions of social workers and the opinions of addiction recoveries about the role of group therapy in developing social relations for those recovering from addiction with their families and colleagues, which indicates the important role of group therapy with addiction recoveries.

Keywords: Group therapy, social relationships, recovering from addiction

\section{Introduction:}

The drug addiction problem is considered one of the most serious problems that affect the building of society and its members due to the bad health and psychological, social and economic effects it has on the individual and on society, and this problem has spread very quickly within society (Volkow, 2009, pp.183-190).

As the statistics indicate that there is an increase in the number of addicts in Egypt as it was estimated at about $9 \%$ of the total population of Egypt, where the number of addicts in 2011 was about 7 million and 290 thousand addicts, and in 2012, their number reached 7 million and 325 thousand addicts. In 2013, their number reached 7 million 650 thousand drug addicts (Central Agency for Public Mobilization and Statistic,2013).

Drawing on the results of the report of the International Narcotics Control Board for the year (2019), it is shown that 31 million people who use drugs around the world suffer from disorders and many of them are young(United Nations Office on Drugs and Crime, 2020, p.1).

The Addiction and Abuse Control and Treatment Fund indicated that the number of those visiting the Fund's services was 129,405 patients during the year 2019, with an increase rate close to doubling compared to 2014, and the service is available in joint treatment centers with the Ministry of Health and Population and 
governmental and private hospitals (Addiction and Abuse Treatment and Control Fund, 2019, p.23).

The results of the study fund for Addiction and Abuse Treatment and Control (2014), indicated that addiction is prevalent among young people whose ages range from 20 years to less than 40 years and that most addicts deviated towards drugs with the encouragement of those close to them and that friends had an effective role in encouraging them.

In spite of the effective role of therapeutic institutions in treating addicts, there is a problem in the post-treatment stage as quite a few addicts have begun to return to abuse again, and this is called the phenomenon of relapse as it is considered a phenomenon opposed to the curative and preventive goals (Wexler, 2000, pp. 33-46).

This is confirmed by the results of Al-Kandari study (2014), where it has found that the most important personal motives that led the relapsing group to obtain treatment with the aim of stopping abuse were that they spent a short period of time in treatment for addiction, and that they were not satisfied with the time period or the program provided to them by institutions. It has become clear that among the most important difficulties faced by the relapsing group after treatment is the weakness of the ability to make positive decisions, the weakness of the ability to think logically, mood changes, a tendency to loneliness and loss of self-confidence, and loss of satisfaction with social relations within the family.

In this regard, the family has a great role in confronting the relapse factors of the recovered from addiction by ensuring a balanced family framework by maintaining family cohesion and methods of dealing with the recovered as well as health, psychological, therapeutic, religious and social rehabilitation for him as one of the most important factors leading to relapse for the recovered is deficiency skills of dealing with social pressures and the inability to form friendships, in addition to the constant absence of parents, tension in relations between them (Frenzel,2001,pp.149-176).

Accordingly, the basic factors of relapse have resulted in the shortcomings of the common concept of addiction, the nature of treatment programs in this field as they are viewed as medical treatment programs, the lack of desire and conviction in joining treatment programs, the effect of the absence of a social concept and the diagnostic mechanism for drug addiction in treatment programs, the neglect of skills Social in treatment programs and sufficiency in medical programs(Jeffrey, 2000). 
In the study of Wasilla (2018), which aimed to test the effectiveness of a group therapy program to alleviate relapse symptoms in drug addicts, it has been observed that $80 \%$ of recovered addicts do not hesitate after leaving the hospital and following the rehabilitation and psychological treatment process, and then they are more vulnerable to relapse, and that the modern rates in Egypt after a five-year follow-up exceed many percentages of treatment abroad. Accordingly, the only place for treating addicts is the governmental and private specialized hospitals for treating addiction, starting from dealing with withdrawal symptoms until the various stages of treatment and rehabilitation (Keith, 1994, p p. 159- 182)

Moreover, the study of Abdullah (2016) aimed to develop a proposed conception from the perspective of group therapy using the self-help group to develop self-confidence among those recovering from drug addiction.

Furthermore, drugs lead to psychological effects in the addict's personality such as anxiety, constant tension, a feeling of instability, and a general perceptual disturbance, which leads to an imbalance in balance, which in turn causes some convulsions and difficulties in speaking and expressing what is going on in the addict's mind. In addition to excess nervousness which results, It necessarily denotes a weak ability to adapt and adapt to others, and drug abuse has many social consequences as it leads the addict to abuse his relationships with his family, colleagues or superiors at work, which leads to problems and loss of values (James, 2002, p. 144).

The study of Ibrahim \& others (2017) aimed to identify methods of confronting problem solving among recovering addicts and to reveal the extent of the difference of these methods through the preparation of an integrated counseling program.

The profession of social work in the medical field is receiving attention from government and private hospitals as it has spread because of scientific progress, which made it an urgent necessity to work with various specialties in all fields. It has also gained community attention and recognition using medical institutions affiliated with the Ministry of Health to appoint social workers to work alongside with other disciplines. Moreover, officials believe in the importance of the social aspect in dealing with the medical side since social work in the medical field does not only contribute to treatment, but rather has its preventive goals by spreading health awareness to prevent addiction, conducting various researches on the 
addict's connection to the surrounding environment, and pointing out the existing treatment services, especially since some addiction factors are closely related to the social aspect, diagnosis and treatment, which makes the social aspect. The role of social work is a vital necessity in group therapy, especially after the importance of social and psychological factors in treatment has become a reality in all theories and scientific studies (Cooper, 1997, p. 8).

Also, the results of the study Brady and Thomas Moore (2002) indicated that group therapy has an important role in diagnosing and treating addicted patients.

Therefore, doctors believe that the treatment provided to addicted patients include group therapy for these groups in order to ensure a rapid return to treatment (Porter, 2007, p. 30). Furthermore, group therapy has many benefits for patients as it helps them positively express their feelings and interact with their surroundings. (Melissa, Patricia, 2012,p. 2).

In addition, the study of Donita's (2015) aimed to highlight the effect of cognitive-behavioral therapy and client-centered group therapy on self-esteem and effectiveness.

It is worth noting that the method of working with groups is one of the methods of the social service profession that uses many therapeutic methods to help addicts recover from addiction, the most important of which is treatment groups, as practitioners use it in various fields. Interest in this method has increased in recent years due to its medical results in dealing with many social problems facing different groups of community members as therapeutic groups contribute to achieving personal and social compatibility of individuals through collective experiences (Obrien, 2016, p.27).

In addition, the study of Ahmad (2020) aimed at testing the effectiveness of a professional intervention program in community service and enhancing recovery motivation among addicted groups.

When these groups are spread in the field of addiction treatment, the social worker focuses on the therapeutic goals of each member more than on the goals of the group itself and works to help those recovering from addiction. The social workerhas an important role in the group therapy within the teamwork, and accordingly the success of the team depends on each member of the team's understanding of his job and their respect to each other. Socially, they have to protect him from relapse and work to strengthen relations between the team, where the specialist exercises his direct role with the group therapy to study the conditions of the group and play the role of facilitator of interaction within the group therapy (Tasland,1984,p.12). 
The study of Qasim (2002) aimed to define the professional role of a social worker with the teamwork to assist the group of addicts in the treatment and prevention of addiction by working with the doctor and the hospital administration in developing and implementing treatment and preventive plans for addicts.

Furthermore, the study of Mansur (2019) aims to determine the requirements of the process of helping the community service to achieve the goals of the group therapy. The social worker performs the helping process through exchanging views with the team in identifying the nature of the family formation of the recovering addict and the amount of damage caused to them from drug abuse in advance and its reflection in his social network within the family or his relationships with colleagues, which may incite him to return to the addiction(Freuden,1990,p.23).

This is emphasized by the study Taher (2017), which aimed at highlighting the role of the social worker with the working group in treatment groups for addicts to integrate them socially.

In this regard, group therapy seek to achieve a set of goals, the most important of which is that the social worker helps addicts express their social problems, increase the sense of self-respect through mutual assistance, provide positivity, increase social support for addicts, develop awareness of their own abilities, follow their social behaviors, and establish a kind of balance and harmony between The addict and his social environment(Bodinham, 2003, p.35).

Through the previous presentation, the main study problem is determined as follows:

What is the role of group therapy in developing social relationships for those recovering from addiction?

\section{Study Objectives:}

1) Determine the role of group therapy in developing social relationships for those recovering from addiction with their families.

2) Determine the role of group therapy in developing social relationships for those recovering from addiction with colleagues. 


\section{Hypotheses:}

First Hypothesis: It is expected that the role of group therapy in developing social relationships for those recovering from addiction with their families is high.

Second Hypothesis: It is expected that the role of group therapy in developing social relationships for those recovering from addiction with colleagues is high.

Third Hypothesis: There are no statistically significant differences between the opinions of social workers and the opinions of those recovering from addiction about the role of group therapy in developing the social relationships for those recovering from addiction with their families.

Fourth Hypothesis: There are no statistically significant differences between the opinions of social workers and the opinions of those recovering from addiction about the role of group therapy in developing the social relationships for those recovering from addiction with colleagues.

\section{Study Concepts}

\section{Social relationships:}

Social relationships mean the mutual interaction that lasts for a certain period and gives rise to a fixed set of social expectations (Nicholas, 1990,p. 14).

\section{Procedural definition of social relationships:}

- Interaction between recovering from addiction and their families. - Interaction between recovering from addiction and their colleagues.

\section{Theoretical Guidelines of the Research:}

\section{The Role Theory:}

The role theory is one of the scientific theories that underpins the method of working with groups, through which it is possible to determine the performance and duties that must be performed by both the social worker and the members of the group, and these roles have an impact on the position that the member occupies within the group. There are many main roles that the social worker plays with addiction recoverers: (Fairbanks, 2007, p. 84)

1)The role related to the fulfillment of group duties as it helps recovered people from addiction alleviate their social problems.

2) The role that has to do with social aspects as it helps to achieve social relations between recovered people from addiction and their families and colleagues. 
3) The role that has to do with the nature of the personalities of the recovered from addiction towards themselves as the personal characteristics of the recovered affect his relationship with his family and colleagues.

4)The role that has to do with improving the professional performance of the social worker during his work with recovered persons from addiction and their relationship with their family and colleagues.

\section{Methodology:}

This study belongs to the pattern of descriptive analytical studies as they describe a specific phenomenon that is addiction recovery.

Sample:

The study was applied toan intentional sample of(25) social worker was selected and (65) recoveries were selected in Bahman, Freedom and Nile Addiction Hospitals who meet the following conditions:

-To be beneficiaries of Bahman, Freedom and Nile Hospitals for addiction treatment.

- To be regular in attending group therapy sessions.

-To have weak social relations with their families and colleagues.

\section{Tool :}

The tools of the study are as follows:

A. A questionnaire applied to social workers about the role of group therapy in developing social relationships for those recovering from addiction.

B. Inquisition applied to recovering from addiction about the role of group therapy in developing social relationships for those recovering from addiction.

\section{The Design of the tool:}

A questionnaire about the role of group therapy in developing social relationships for those recovering from addiction, and inquisition about the role of group therapy in developing social relationships for those recovering from addiction was designed according to the following steps: researchers benefit from previous studies about recovering from addiction, the answer on the questionnaire and inquisition items are determined as follows: totally agree $=5$ degrees, agree $=4$ degrees, almost Agree $=3$ degrees, not agree $=2$ degrees, not totally agree $=1$ degree. To calculate the role of group therapy in developing social relationships for those recovering from addiction, we used the arithmetic mean as shown in Table (3). 
Table (1):The arithmetic mean levels of the phrases and Dimensions of the questionnaire and inquisition

\begin{tabular}{|c|c|}
\hline $\begin{array}{l}\text { If it is the mean value of the phrase or dimension ranged between } 1 \\
\text { and } 2.33\end{array}$ & Low levels \\
\hline $\begin{array}{l}\text { If it is the mean value of the phrase or dimension ranged between } \\
2.33 \text { and } 3.66\end{array}$ & Medium level \\
\hline $\begin{array}{l}\text { If it is the mean value of phrase or dimension ranged between } 3.66 \\
\text { and } 5\end{array}$ & High level \\
\hline
\end{tabular}

Validity and Reliability of the Study Tool:

\section{Content validity:}

Experienced reviewers in the field judged the questionnaire and inquisition (2) members of working with groups department and (2) member of social work fields department in the Faculty of Social Work, Helwan University. The members approved the questionnaire and inquisition with more than $85 \%$ rate.

\section{Internal consistency:}

The researchers used internal consistency by applying a questionnaire toa sample of (25) social workers in Bahman hospitals, Nile and Freedom for addiction, and applying inquisition to a sample of (65) recovering from addiction in Bahman hospitals, Nile and Freedom for addiction.

\section{Study results:}

\section{Characteristics of the study sample}

Table (2): Shows the primary data for social workers $(\mathbf{N}=25)$

\begin{tabular}{|c|c|c|c|}
\hline $\mathrm{S}$ & Age & $\mathrm{N}$ & $\%$ \\
\hline 1 & From 25 to 35 years old & 9 & 36.0 \\
\hline 2 & From 35 to 45 years old & 14 & 56.0 \\
\hline 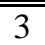 & From 45 to 55 years old & $\overline{2} 2$ & 8.0 \\
\hline$\overline{\mathrm{S}}$ & Gender & $\mathrm{N}$ & $\%$ \\
\hline 1 & Male & 16 & 64.0 \\
\hline 2 & Female & 9 & 36.0 \\
\hline$\overline{\mathrm{S}}$ & Educational qualification & $\overline{\mathrm{N}}$ & $\%$ \\
\hline 1 & Intermediate diploma in social work & 2 & 8.0 \\
\hline 2 & Bachelor of Social Work & 16 & 64.0 \\
\hline 3 & Postgraduate Diploma in Social Work & 1 & 4.0 \\
\hline 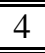 & Master of Social Work & 3 & 12.0 \\
\hline 5 & PhD in social work & 3 & 12.0 \\
\hline $\mathrm{S}$ & Years of experience in the field of work & $\mathrm{N}$ & $\%$ \\
\hline 1 & Less than 2 years & - & - \\
\hline 2 & From 2 to less than 4 years & 9 & 36.0 \\
\hline
\end{tabular}




\begin{tabular}{|c|c|c|c|}
\hline 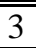 & From 4 to less than 6 years & 8 & 32.0 \\
\hline 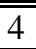 & From 6 years and over & $\overline{88}$ & 32.0 \\
\hline $\mathrm{S}$ & Functional status & $\mathrm{N}$ & $\%$ \\
\hline 1 & Social worker & 16 & 64.0 \\
\hline 2 & Supervisor of activities & 7 & 28.0 \\
\hline 3 & Director of the Department & 2 & 8.0 \\
\hline
\end{tabular}

The table above shows that:

- The description of social workers in terms of age came in the first order (from 35 to 45 years) with a percentage (56.0\%), and this confirms that most social workers working with recovering addicts are experienced in the field and are not new to working with addiction recoverers. Moreover, it came in the last order (from 45 to 55 years old) with a rate of $(8.0 \%)$, and it is certain that this age stage is more related to managers rather than social workers.

- The description of social workers in terms of gender revealed that the largest percentage of males is $(64.0 \%)$, and this may be the nature of the age stage that the recovering addict is going through as it was found from the following table that they are from the youth group.

- The description of social workers in terms of educational qualification came in the first order (Bachelor's in Social Work) at a rate of $(64.0 \%)$. This shows the importance of the social work profession in helping recovered people from addiction in developing their social relations and came in the last order (Postgraduate Diploma in Service, Social sector) at (4.0\%).

- The description of social workers in terms of years of experience in the field of work came in the first order (from 2 to less than 4 years) with a percentage (36.0\%), followed by (from 4 to less than 6 years), (from 6 years or more) with a percentage (32.0\%), which confirms the importance of the experience available to specialists working with addiction recovery.

- The description of social workers in terms of job status (social worker) at a rate of $(64.0 \%)$, which stresses that he is the person who is theoretically and practically prepared and is responsible for developing social relations among addiction recoverers. 
Table (3)shows the primary data for recovering from $\operatorname{addiction}(\mathbf{N}$ $=65$ )

\begin{tabular}{|c|c|c|c|}
\hline $\mathrm{S}$ & Age & $\overline{\mathrm{N}}$ & $\%$ \\
\hline 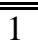 & "Less than 18 years & 22 & 33.8 \\
\hline$\overline{2}$ & $18-23$ years & 19 & 29.2 \\
\hline 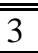 & $23-28$ years & 21 & 32.3 \\
\hline$\overline{44}$ & 28 years and over & 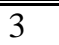 & 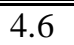 \\
\hline$\overline{\mathrm{S}}$ & Gender & $\overline{\mathrm{N}}$ & $\%$ \\
\hline 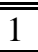 & Male & 39 & 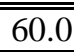 \\
\hline 2 & Female & 26 & 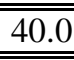 \\
\hline 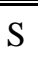 & Educational level & $\overline{\mathrm{N}}$ & $\%$ \\
\hline 1 & Illiterate & 15 & 23.1 \\
\hline 2 & Read and write & 21 & 32.3 \\
\hline 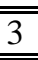 & Primary & 1 & 1.5 \\
\hline 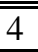 & Preparatory & 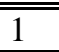 & 1.5 \\
\hline 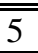 & Secondary & 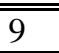 & 13.8 \\
\hline 6 & Bachelors degree & 18 & 27.7 \\
\hline$\overline{\bar{S}}$ & The monthly income of the family & $\overline{\mathrm{N}}$ & $\%$ \\
\hline 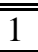 & From 2000 - 2500 pounds & 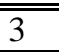 & 4.6 \\
\hline$\overline{2}$ & From 2500 - 3000 pounds & 10 & 15.4 \\
\hline 3 & From 3000 - 3500 pounds & 14 & 21.5 \\
\hline 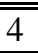 & From 3500 - 4000 pounds & 13 & 20.0 \\
\hline$\overline{5}$ & 4000 pounds or more & 25 & 38.5 \\
\hline
\end{tabular}

The table above shows that:

- The people recovered from addiction described the study population in terms of age as it came in the first place (less than 18 years) with a rate of (33.8\%), and came in the last order (from 28 years and over) with a rate $(4.6 \%)$, which confirms that the youth group is more prone to addiction.

- The description of addiction recoverers in terms of gender showed that the largest percentage of addiction recoverers are males $(60.0 \%)$, which indicates that males are more likely to be addicted to substance abuse.

- The description of those recovering from addiction in terms of educational level as it came in the first order (read and write) by (32.3\%), and came in the last order (primary), (intermediate) by $(1.5 \%)$, which indicates that the person's drug use is not affected by the educational level of the recovered. 
- The description of those recovering from addiction in terms of monthly income of the family as it came in first order (4000 pounds or more) with a percentage $(38.5 \%)$, and this indicates that addiction treatment requires high income due to the high cost.

\section{Results of the Field Study:}

Testing the study hypothesis

Table (4)shows the level of the role of group therapy in developing social relationships for those recovering from addiction with their families

\begin{tabular}{|c|c|c|c|c|c|c|}
\hline$\overline{\bar{S}}$ & $\overline{\text { Category }}$ & the variable & 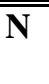 & mean & $\begin{array}{l}\text { weighted } \\
\text { average }\end{array}$ & 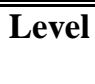 \\
\hline 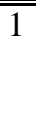 & $\begin{array}{l}\text { Social } \\
\text { workers }\end{array}$ & \multirow{2}{*}{$\begin{array}{l}\text { the role of group therapy in } \\
\text { developing social } \\
\text { relationships for those } \\
\text { recovering from addiction } \\
\text { with their families }\end{array}$} & 25 & 4.19 & 0.416 & High \\
\hline 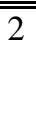 & $\begin{array}{l}\text { Recovering } \\
\text { from } \\
\text { addiction }\end{array}$ & & "65 & 4.28 & 0.361 & "High \\
\hline
\end{tabular}

The table above shows that:

-The level of the role of group therapy in developing the social relationships of those recovering from addiction with their families, as determined by social workers was high, with an average of (4.19) of my weight.

- The level of the role of group therapy in developing the social relationships of those recovering from addiction with their families, as determined by those recovering from addiction was high with an average of (4.28) of my weight, which makes us accept the first hypothesis of the study, which "it is expected that the level of the role of group therapy in developing the social relationships of people recovering from addiction with their families is high". This confirms the effectiveness of therapeutic groups in developing relationships between the recovering and their families, and this is consistent with the results of the study of (Rashad Abdel Hamid, 2011) and (Azza Abdel Jalil, 2009), which emphasized the importance of the role of social workers in working in the psychological field and helping the recovering from addiction to relieve severity of their social problems. 
Table (5)shows the level of the role of group therapy in developing social relationships for those recovering from addiction with colleagues

\begin{tabular}{|c|c|c|c|c|c|c|}
\hline$\overline{\mathbf{S}}$ & $\overline{\text { Category }}$ & the variable & $\mathbf{N}$ & mean & $\begin{array}{l}\text { weighted } \\
\text { average }\end{array}$ & $\overline{\text { Level }}$ \\
\hline 1 & $\begin{array}{l}\text { Social } \\
\text { workers }\end{array}$ & \multirow{2}{*}{$\begin{array}{l}\text { of the role of group therapy } \\
\text { in developing social } \\
\text { relationships for those } \\
\text { recovering from addiction } \\
\text { with colleagues }\end{array}$} & 25 & 4.16 & 0.353 & High \\
\hline$\overline{2}$ & $\begin{array}{l}\text { Recovering } \\
\text { from } \\
\text { addiction }\end{array}$ & & 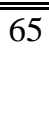 & 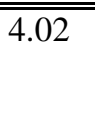 & 0.372 & "High \\
\hline
\end{tabular}

The table above shows that:

- The level of the role of grouptherapy in developing the social relationships of those recovering from addiction with their colleagues, as determined by social workers, was high, with an average of (4.16) of my weight.

- The level of the role of grouptherapy in developing the social relationships of those recovering from addiction with their colleagues, as determined by those recovering from addiction, was high, with an average of my weight (4.02), which makes us accept the second hypothesis of the study, which is"it is expected that the level of the role of grouptherapy in developing the social relationships of people recovering from addiction with their colleagues is high". This is consistent with the results of the study of (Najla Taher, 2017) and (Ahmed Saad, 2012), where they emphasized the importance of therapeutic groups and their role in achieving social integration for the addicted category, in addition to contributing to the rehabilitation of those recovering from addiction. 


\begin{tabular}{|lr||}
\hline Egyptian Journal of Social Work (EJSW) & http://ejsw.journals.ekb.eg \\
ISSN: 2356-9204 & Vol 13, Issue 1, January 2022 \\
\hline
\end{tabular}

Table (6)shows the differences between the opinions of social workers and the opinions of addiction recoverers about the role of group therapy in developing social relationships for those recovering from addiction with their families

\begin{tabular}{|c|c|c|c|c|c|c|c|c|}
\hline$S$ & Category & the variable & Sample & $\begin{array}{l}\text { weighted } \\
\text { average }\end{array}$ & (SD) & $\begin{array}{l}\text { value } \\
\text { F }\end{array}$ & $\begin{array}{l}\text { value } \\
\mathrm{T}\end{array}$ & DF \\
\hline 1 & $\begin{array}{l}\text { Social } \\
\text { workers }\end{array}$ & \multirow{2}{*}{$\begin{array}{l}\text { the role of } \\
\text { group } \\
\text { therapy in } \\
\text { developing } \\
\text { social } \\
\text { relationships } \\
\text { for those } \\
\text { recovering } \\
\text { from } \\
\text { addiction } \\
\text { with their } \\
\text { families }\end{array}$} & 25 & "4.19 & 0.416 & \multirow[t]{2}{*}{1.0815} & \multirow[t]{2}{*}{1.020} & \multirow[t]{2}{*}{88} \\
\hline 2 & $\begin{array}{l}\text { Recovering } \\
\text { from } \\
\text { addiction }\end{array}$ & & 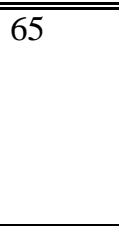 & 4.28 & 0.361 & & & \\
\hline
\end{tabular}

** Significance at $(0.01)$

The table above shows that:

There were no significant differences between the opinions of social workers and the opinions of addiction recoverers about the role of group therapy in developing social relationships for those recovering from addiction with their families, as the value of the $\mathrm{T}$ test was (1.020), which is not significant. This makes us accept the third hypothesis of the study, which is that: "There are no statistically significant differences between the opinions of social workers and the opinions of drug addicts about the role of therapeutic groups in developing social relations of drug addicts with their families". This is consistent with the study of (Afaf Adel, 2012) and (Geibel 2000), which confirmed the effectiveness of the task-focused model in rehabilitating families of addicts for the post-treatment stage, in addition to the fact that regular attendance at group therapy sessions reduces the incidence of relapse and helps toincrease psychological and social compatibility. 


\begin{tabular}{|lr||}
\hline Egyptian Journal of Social Work (EJSW) & http://ejsw.journals.ekb.eg \\
ISSN: 2356-9204 & Vol 13, Issue 1, January 2022 \\
\hline
\end{tabular}

Table (7)shows the differences between the opinions of social workers and the opinions of addiction recoverers about the role of group therapy in developing social relationships for those recovering from addiction with colleagues

\begin{tabular}{|c|c|c|c|c|c|c|c|c|}
\hline $\mathbf{S}$ & Category & the variable & Sample & $\begin{array}{l}\text { weighted } \\
\text { average }\end{array}$ & (SD) & $\begin{array}{l}\text { value } \\
\mathrm{F}\end{array}$ & $\begin{array}{l}\text { value } \\
\mathbf{T}\end{array}$ & DF \\
\hline 1 & $\begin{array}{l}\text { Social } \\
\text { workers }\end{array}$ & \multirow{2}{*}{$\begin{array}{l}\text { the role of } \\
\text { group } \\
\text { therapy in } \\
\text { developing } \\
\text { social } \\
\text { relationshi } \\
\text { ps for } \\
\text { those } \\
\text { recovering } \\
\text { from } \\
\text { addiction } \\
\text { with } \\
\text { colleagues }\end{array}$} & 25 & 4.16 & 0.353 & \multirow[t]{2}{*}{0.198} & \multirow[t]{2}{*}{1.567} & \multirow[t]{2}{*}{88} \\
\hline 2 & $\begin{array}{l}\text { Recovering } \\
\text { from } \\
\text { addiction }\end{array}$ & & 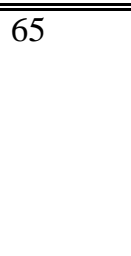 & 4.02 & 0.372 & & & \\
\hline
\end{tabular}

** Significance at (0.01)

The table above shows that:

There were no significant differences between the opinions of social workers and the opinions of addiction recoverers about the role of group therapy in developing social relationships for those recovering from addiction with colleagues, as the value of the T-test was (1.567), which is not significant. This makes us accept the fourth hypothesis of the study, which is there are no statistically significant differences between the opinions of social workers and the opinions of addiction recoverers about the role of grouptherapy in developing social relationships for those recovering from addiction with their colleagues.This is consistent with the study of (Mubarak Saad, 2013) and (Saeed Hassanein, 2009), which confirmed the effectiveness of psychological counseling for meaning therapy in improving the meaning of life for convalescent addicts from addiction with their colleagues, and thus develop their abilities to deal with life situations.

\section{Discussion:}

The results of the study proved the validity of the presently hypotheses:

1- The role of grouptherapy in developing social relationships for those recovering from addiction with their families is high. 
2- The role of group therapy in developing the social relationships of those recovering from addiction with colleagues is high.

3- There are no statistically significant differences between the opinions of social workers and the opinions of addiction recoverers about the role of group therapy in developing social relations for those recovering from addiction with their families.

4- There are no statistically significant differences between the opinions of social workers and the opinions of addiction recoverers about the role of group therapyin developing the social relationships of people recovering from addiction with colleagues.

\section{Statistical procedures used in the study:}

- The data were processed by computer using the program (SPSS. V. 24.0) statistical packages for social sciences. The following statistical methods were applied:frequencies, percentages, arithmetic mean, standard deviation, range and T-test for two independent samples.

- The level of the role of group therapy in developing the social relationships of people recovering from addiction was judged using the arithmetic mean, where the beginning and end of the five-point scale categories are: totally agree $=5$ degrees, agree $=4$ degrees, almost Agree $=3$ degrees, not agree $=2$ degrees, not totally agree $=1$ degree. The data was coded and entered into the computer, and to determine the length of the triple scale cells (lower and upper limits), the range $=$ largest value - lowest value $(5-1=4)$ was calculated, divided by the number of scale cells to obtain the corrected cell length $(4 / 3=1.33)$. Then this value was added to the lowest value in the scale or the beginning of the scale, which is the correct one, to determine the upper limit for this cell.

\section{Recommendations:}

The current study recommends:

1-Paying attention to research on the causes that lead to addiction and deal with them.

2- Focusing on the role of group therapy in drug addiction treatment institutions because of their effective role in reaching the addict a complete recovery.

3- Focusing on research that develops social communication between addicts, their families and the surrounding community.

4- The need to develop families' awareness of the importance of early detection of addiction and its relationship to rapid recovery. 


\section{Difficulties encountered in the search:}

-Difficulty obtaining security approvals due to the Corona pandemic.

- The length of the application period due to the irregularity of those recovering from addiction to attend group therapy sessions due to the Corona pandemic.

\section{References:}

Abdullah, Tariq Muharram (2016). a proposed conception from the perspective of group therapy using a self-support group to develop self-confidence in those recovering from drug addiction: Journal of Social Service, Vol. 7, no. 56, Egyptian Society of Social Workers, p p. 347- 414.

Abdul-Aziz, Azza Abdel Jalil (2009). Activating the professional practice of the group service method in light of contemporary societal issues to alleviate the social problems facing groups, the twenty-second scientific conference, Volume Three, Faculty of Social Work, and Helwan University.

Adel, Afaf (2012). the Effectiveness of the Task Focusing Model in Rehabilitation of the Families of Civilians for the Post-Treatment Stage and Its Relation to Reducing Relapse Rates: Master Thesis, Cairo.

Addiction and Abuse Treatment and Control Fund(2019). Activities report, Cairo.

Ahmad, Ahmad Mohammed (2020). practice a program in the social group work to enhance the motivation of recovery among drug addicts groups: $\mathrm{PhD}$ thesis, Faculty of Social Work, Helwan University.

Al-Kandari, Haifa Yusuf (2014). Factors that help relapse among recovered drug addicts from relapsed people compared to those in Kuwaiti society: Journal of Social Sciences, Vol. 42, no. 2, p p. 11-47.

Al-Nahhas, Ahmed Saad (2012). Evaluating the professional role in rehabilitation for recovering from addiction, unpublished master's thesis, Faculty of Social Work, Helwan University.

Barber, James (2002). Social Work with Addiction: New York, and Palgrave MacMillan books.

Bodinham, H, and Weinstein (2003). Group theory with adults with developmental disabilities: California, state council.

Brady, Thomas Moore (2002). Retention of substance abuse welfare reform: $\mathrm{PhD}$ thesis, United States, Illinois.

Casey, Obrien (2016). the process behind group therapy: California, United States, ProQuest books.

Central Agency for Public Mobilization and Statistics (2013). statistics on drug addiction and drug issues: the annual statistical book

Chandler, R.K, Fletcher B.W\& Volkow, N.D (2009). Treating drug abuse and addiction in the criminal justice system: the journal of the American medical association, vol. 2, no. 25, p p. 183-190.

Charles, Zastrow(1986). Social Welfare Institution: the Dorsey press, third edition, chicago.u.s.a.

Colleen M. Fairbanks (2007). role theory and care giving attributes in adult child caregivers role strain: Indian, ProQuest books.

Cyrus S. Behroozi (1974). relationships among value definition and practice competence in social work: California, United States, ProQuest books. 
Donita, smith (2015).the impact cognitive behavioral group therapy and client centered group therapy on the self esteem and self efficacy of at risk adolescents in an alternative school based setting, Capella, university, ProQuest books.

Dudley\& Keith(1994). positive peer culture and Adults, journal of behavior al disorder, vol .5, no. 3, p p. 159-182.

Fund for the Combating and Treatment of Addiction and Abuse (2014). a comprehensive survey of the phenomenon and drug addiction "A study on inmates of treatment departments": Cairo, National Center for Criminal and Social Research.

Geibel S. Jeffrey (2000).the relationship between approach and avoidance coping strategies and substance abuse relapse in adult substance abusers: PhD thesis, California, Say brook Graduate School and Research Center.

Ibrahim, Shaima Ismail \& others (2017). Development of problem-solving strategies for recovering addicts: Journal of Scientific Research in Literature, vol. 2, no. 18, Girls' College of Arts, Sciences and Education, Ain Shams University, p p. 399-438.

Ibrahim, Hussein Mansur (2019). Requirements for the Help Process in group work to Achieve group therapy Goals: Master Thesis, Faculty of Social Work, Helwan University.

Leon, G.D, Mel nick, Thomas, kersey, Wexler, H.K (2000). Motivation for treatment in a person based therapeutic community: the American journal of drug and alcohol abuse, vol. 1, no. 26, p p. 33-46.

Lisa B, Freuden (1990). the successful incomplete in group therapy: California, United States, ProQuest books.

Melissa Harper, Patricia Cole (2012). Member checking: Can benefits be gained similar to group therapy: the qualitative report, vol.17, no.2.

Muhammad, Saad Mubarak (2013). the Effectiveness of Counseling with Meaning in Improving the Meaning of Life for a camel Addict: Saudi Arabia, Master Thesis, Saudi Arabia.

Nathan, Cooper (1997). criteria for selection of individuals for group therapy: California, United States, ProQuest books.

Porter, Hayley Ilana (2007). clinician's views on social support as the determining variable in substance abuse treatment for individuals: meeting criteria for borderline personality disorder, United States, Illinois, $\mathrm{PhD}$ thesis.

Qasim, Mustafa Muhammad (2002). The use of the social worker in the medical field of the skills of the help process: the fifteenth scientific conference, vol.4, Faculty of Social Work, Helwan University, p p. 133- 152

Ratab, Wassila (2018). The Effectiveness of a Group Therapy Program to Alleviate Relapse Symptoms in Drug Addicts: PhD Thesis, Faculty of Humanities and Social Sciences, University of Dr. Mohamed Lamine Dabbaghine Setif.

Spohn, C, Piper, R.K, Martin, T\& Frezel, E.D (2001). Drug courts and recidivism: the journal of drug issues, vol. 1, no. 31, p p. 149-176.

Steve \& Alan N. Sussman (2011). considering the definition of addiction: Virginia, international journal of environmental research and public health, vol. 2, no. 25, p p. 4025-4038. 


\begin{tabular}{|lr||}
\hline Egyptian Journal of Social Work (EJSW) & http://ejsw.journals.ekb.eg \\
ISSN: 2356-9204 & Vol 13, Issue 1, January 2022 \\
\hline \hline
\end{tabular}

Seddik, Rashad Abdel Hamid (2011). Evaluating the roles of the specialist as a general practitioner with dealing patterns in mental health departments in university hospitals, Master's thesis, unpublished, Faculty of Social Work, Helwan University.

Taher, Naglaa Abdel-Razek (2017). the roles of the social worker with the team work in treatment groups for addicts to integrate them socially: master's thesis, Faculty of Social Work, Helwan University.

Tasland W. Ronlad (1984), an introduction to group work practice: N, Y Macmillan Company, United States, ProQuest books.

United Nations Office on Drugs and Crime (2020). Report of the International Narcotics Control Board.

Wilmerding, MaryNicholas (1990). the relationship between early group laughter and group cohesiveness in outpatient psychotherapy groups: PhD thesis, California, United States, ProQuest. 